\title{
GINGEROL PADA RIMPANG JAHE MERAH (Zingiber officinale, Roscoe) DENGAN METODE PERKOLASI TERMODIFIKASI BASA
}

\author{
Lilis Sugiarti*, Asridewi Suwandi dan Amry Syawaalz \\ *Fakultas MIPA Universitas Nusa Bangsa \\ Jalan Baru Km 4 Cimanggu, Tanah Sareal, Bogor 16166 \\ Telp (0251) 8340217, 7535605, 7538760 Fax. (0251)7535605 \\ *e-mail : lilis_suwarno@yahoo.co.id
}

\begin{abstract}
Gingerol in red ginger (Zingiber officinale, Roscoe) with percolation method modified base
\end{abstract}

\begin{abstract}
Ginger was a spice type most widely used in various food and beverage recipes. Ginger is commonly used as a medicine at colds, indigestion, as an analgesic, anti-inflammatory, and others. Some of main components in ginger such as gingerol and shogaol are antioxidants. The purpose of this research was to isolate the red-gingerol in ginger rhizome and to identify. Metode used was extraction process by using percolation with ethanol solvent at room temperature, followed by isolation of gingerol by adding $\mathrm{KOH}$ solution at concentrations of $0,1 \mathrm{~N}, 0.5 \mathrm{~N} ; 1.0 \mathrm{~N}$. Furthermore, the extracted of compounds were identified using TLC and GC-MS.Based on the research result and identification had been carried out on samples of red ginger, it could be concluded that the water content of red ginger samples were $9.70 \%$, with levels of $8.72 \%$ oleoresin. The weight of crude gingerol obtained in $1.0 \mathrm{~N} \mathrm{KOH}$ concentration was to $0.61 \mathrm{~g}$, while the concentration of $\mathrm{KOH}$ that produces greatest gingerol was $0.5 \mathrm{~N}$, which amounted of $6.13 \%$. The other peak than the gingerol peak suggested that the isolation was not pure yet. Homovanilil alcohol compounds was always in the greatest prosentase, which was $22 \%$, followed by shogaol compounds of $4.30 \%$. Ion with a value $137 \mathrm{of} \mathrm{m} / \mathrm{e}$ : was the highest ions to be formed and the most stable ion Most compounds isolated by KOH were phenolic compounds groups, such as gingerol, shogaol and homovanilil alcohol.
\end{abstract}

Keywords: red ginger, gingerol, extraction, TLC, GC-MS

\begin{abstract}
ABSTRAK
Jahe merupakan jenis rempah-rempah yang paling banyak digunakan dalam berbagai resep makanan dan minuman. Jahe biasa digunakan masyarakat sebagai obat masuk angin, gangguan pencernaan, sebagai analgesik, anti-inflamasi, dan lain-lain. Beberapa komponen utama dalam jahe seperti gingerol dan shogaol bersifat antioksidan. Adapun tujuan penelitian ini dilakukan adalah untuk mengisolasi gingerol pada rimpang jahe merah secara optimum dan mengidentifikasinya.Metode penelitian yang digunakan meliputi proses ekstraksi jahe merah dengan menggunakan teknik ekstraksi perkolasi suhu ruang dengan pelarut etanol, dilanjutkan dengan isolasi gingerol dengan penambahan larutan $\mathrm{KOH}$ pada konsentrasi $0,1 \mathrm{~N} ; 0,5 \mathrm{~N} ; 1,0 \mathrm{~N}$. Selanjutnya senyawa hasil ekstraksi diidentifikasi dengan menggunakan TLC dan GC-MS. Berdasarkan hasil penelitian dan identifikasi yang telah dilakukan pada sample jahe merah, dapat disimpulkan bahwa kadar air sampel jahe merah yang diteliti adalah sebesar $9,70 \%$, dengan kadar oleoresin sebesar 8,72\%. Bobot kasar gingerol terbesar diperoleh pada konsentrasi $\mathrm{KOH} 1,0 \mathrm{~N}$ yaitu sebesar $0,61 \mathrm{~g}$, sedangkan konsentrasi $\mathrm{KOH}$ yang menghasilkan \%kemelimpahan gingerol terbesar adalah pada konsentrasi $0,5 \mathrm{~N}$, yaitu sebesar $6,13 \%$. Adanya puncak lain selain gingerol menunjukkan bahwa hasil isolasi belum murni. Senyawa homovanilil alkohol selalu terdapat dengan $\%$ kemelimpahan terbesar pada setiap sample, yakni $22 \%$, diikuti senyawa shogaol sebesar $4,30 \%$. Ion dengan nilai $\mathrm{m} / \mathrm{e}$ : 137 adalah ion yang paling banyak terbentuk dan merupakan ion yang stabil. Sebagian besar senyawa yang terisolasi oleh $\mathrm{KOH}$ adalah senyawa golongan fenol, seperti gingerol, shogaol dan homovanilil alkohol.
\end{abstract}

Kata kunci : jahe merah, gingerol, ekstraksi, TLC, GC-MS 


\section{PENDAHULUAN}

Jahe merupakan rempah - rempah yang paling banyak digunakan dalam berbagai resep makanan dan minuman. Jahe yang merupakan salah satu komoditas ekspor Indonesia, volume permintaannya terus meningkat seiring dengan permintaan produk jahe di dunia serta makin berkembangnya industri makanan dan minuman di dalam negeri yang menggunakan bahan baku jahe. Data tahun 2003 menunjukkan volume ekspor jahe mencapai 7.470 ton, dan mengalami peningkatan setiap tahunnya. Kondisi ini di Indonesia, direspon dengan semakin berkembangnya areal penanaman dan munculnya berbagai produk jahe (Rostiana et al., 2005).

Jahe biasa digunakan masyarakat sebagai obat masuk angin, gangguan pencernaan, sebagai analgesik, antiinflamasi, dan lain-lain. Berbagai penelitian membuktikan bahwa jahe mempunyai sifat antioksidan. Beberapa komponen utama dalam jahe seperti gingerol dan shogaol memiliki aktivitas antioksidan (Winarti et al., 2005). Gingerol pada jahe bersifat antikoagulan, yaitu mencegah penggumpalan darah, sehingga mencegah tersumbatnya pembuluh darah, yang merupakan penyebab utama stroke, dan serangan jantung. Selain itu, gingerol dan shogaol mempunyai aktivitas antireumatik (Winarti et al., 2005). Merdhikawati (2006), menyatakan bahwa teknik ekstraksi perkolasi suhu ruang pada jahe merah dengan pelarut etanol mampu mendapatkan kadar [6]-gingerol dan rendemen oleoresin sebesar $0.33 \%$. Tapi penelitian ini hanya sampai diperoleh oleoresin saja, belum sampai pada tahap isolasi gingerol. Hayati (2005) melakukan isolasi gingerol pada rimpang jahe emprit menggunakan metode ekstraksi sokhlet dengan larutan petroleum eter dan dilanjutkan dengan aseton, kemudian dimurnikan dengan kromatografi kolom. Hasil penelitian didapatkan konsentrasi gingerol sebesar $0.13 \%$. Kecilnya nilai konsentrasi gingerol disebabkan oleh terdegradasinya senyawa gingerol selama proses isolasi. Selain itu, terdapatnya puncak lain pada kromatogram menunjukkan bahwa hasil isolasi belum murni.

Berdasarkan penelitian-penelitian di atas, terlihat bahwa gingerol dapat diidentifikasi dari hasil ekstrak jahe, namun masih belum mendapatkan hasil yang memuaskan. Untuk itu perlu penelitian lebih lanjut mengenai metode pemisahan gingerol dari ekstraknya, sehingga gingerol dapat lebih mudah dipisahkan dan dimurnikan dari komponen getirnya dengan hasil yang memuaskan (optimum).Penelitian ini bertujuan untuk mengektraksi gingerol pada rimpang jahe merah agar didapatkan gingerol dengan jumlah yang lebih besar dan dalam kondisi yang lebih murni.

\section{BAHAN DAN METODE}

Metode penelitian yang digunakan meliputi proses ekstraksi jahe merah berdasarkan metode Merdhikawati (2006), yakni menggunakan teknik ekstraksi perkolasi suhu ruang dengan pelarut etanol. Dilanjutkan dengan ekstraksi gingerol dengan penambahan larutan $\mathrm{KOH}$ pada konsentrasi $0,1 \mathrm{~N}, 0,5 \mathrm{~N}, 1,0 \mathrm{~N}$, dan tahap akhir dengan melakukan identifikasi senyawa gingerol dari hasil ekstraksi gingerol dengan menggunakan TLC (KLT) Scanner dan GC-MS.

Pada tahap awal, jahe merah dibersihkan dengan air kemudian dikeringanginkan dan dibagi menjadi dua kelompok (jahe merah segar dan jahe merah untuk dikeringkan). Pada jahe merah segar yang telah dibersihkan, dilakukan analisis kadar air. Sedangkan perlakuan untuk memperoleh senyawa aktif gingerol, jahe merah diiris - iris, dikeringkan dengan kipas angin, dan dihaluskan menggunakan blender hingga lolos saringan 40 mesh.

Bubuk jahe ditimbang sebanyak $100 \mathrm{~g}$ kedalam gelas piala $250 \mathrm{ml}$. Setelah itu ditambahkan $300 \mathrm{ml}$ etanol $96 \%$ lalu diaduk dengan stirer selama 1 jam pada suhu kamar. Sampel disaring dengan kertas saring, dan filtrat ditampung pada gelas piala yang telah disiapkan dan disimpan. Residu ditambahkan lagi $300 \mathrm{ml}$ etanol 
96\% dan diaduk selama 1 jam, disaring dan filtrat ditampung pada tempat yang sama. Perlakuan ini diulang sebanyak $2 \mathrm{x}$. Selanjutnya total filtrat diuapkan pelarutnya dengan proses destilasi, dan ekstrak ditimbang. Total ekstrak dimasukkan ke dalam labu pemisah (1) dan ditambahkan $50 \mathrm{ml}$ kloroform, lalu dikocok selama 5 menit pada suhu kamar. Larutan yang berada di lapisan bawah (fase organik) dipindahkan kedalam labu pemisah (2) yang telah disiapkan. Kemudian ditambahkan kembali $50 \mathrm{ml}$ kloroform kedalam labu pemisah (1), lalu dikocok selama 50 menit. Larutan yang berada di lapisan bawah (fase organik) ditampung pada tempat yang sama. Perlakuan ini diulang sebanyak 2x. Selanjutnya total larutan yang berada pada labu pemisah (2) ditambahkan $50 \mathrm{ml} \mathrm{KOH}$ $0,1 \mathrm{~N}$, lalu dikocok selama 5 menit pada suhu kamar. Larutan yang berada di lapisan bawah dipindahkan kedalam gelas piala (a), dan larutan yang berada di lapisan atas dipindahkan kedalam gelas piala (b). Setelah itu, larutan yang berada di dalam gelas piala (a) dimasukkan kembali ke dalam labu pemisah (2), lalu ditambahkan $50 \mathrm{ml} \mathrm{KOH} \quad 0,1 \mathrm{~N}$, dan dikocok selama 5 menit. Larutan yang berada di lapisan bawah dipindahkan kedalam gelas piala (a), dan larutan yang berada di lapisan atas dipindahkan kedalam gelas piala (b). Perlakuan ini diulang sebanyak $2 x$. Selanjutnya total larutan dalam gelas piala (b) dinetralkan dengan $\mathrm{HCl} 5 \%$. Setelah itu larutan dimasukkan ke dalam labu pemisah (3) dan kembali diekstrak dengan $50 \mathrm{ml}$ Kloroform, lalu dikocok selama 5 menit pada suhu kamar. Larutan yang berada di lapisan bawah (fase organik) dipindahkan kedalam labu pemisah (4) yang telah disiapkan. Kemudian larutan ditambahkan kembali $50 \mathrm{ml}$ kloroform kedalam labu pemisah (3), lalu dikocok kembali selama 5 menit. Larutan yang berada di lapisan bawah (fase organik) dipindahkan pada tempat yang sama. Perlakuan ini diulang $2 x$. Selanjutnya total filtrat didiamkan di dalam ruangan selama satu minggu untuk menghilangkan pelarutnya. Perlakuan di atas dilakukan kembali dengan menggunakan larutan $\mathrm{KOH} 0,5 \mathrm{~N}$ dan $1,0 \mathrm{~N}$ dari 100gr bubuk jahe.

Plat KLT yang digunakan yaitu silika GF 60 plat alumunium, yang diaktifkan terlebih dahulu selama 1 jam pada oven $100^{\circ} \mathrm{C}$. Larutan heksana dan dietil eter dengan perbandingan $3: 7$ dicampurkan dan dijenuhkan didalam bejana pengembang. Ekstrak ditotolkan pada plat KLT yang telah diberi tanda batas. Kemudian dimasukkan kedalam cawan pengembang yang telah jenuh dengan pelarut, lalu dibiarkan hingga pelarut mencapai garis tanda batas. Spot yang diperoleh dapat dilihat di bawah sinar UV pada panjang gelombang $254 \mathrm{~nm}$.

\section{Analisis Data}

Analisis data dalam penelitian ini adalah berdasarkan hasil kromatogram gingerol yang diperoleh pada identifikasi dengan menggunakan GC-MS. Semakin banyak puncak lain pada kromatogram (selain gingerol), menunjukkan bahwa isolasi belum murni. Dan semakin besar \% kemelimpahan gingerol, menunjukkan semakin besar kelimpahan gingerol.

\section{HASIL DAN PEMBAHASAN}

Kadar air yang diperoleh pada sampel jahe merah adalah sebesar 9,70\%. Nilai tersebut masih memenuhi standard SNI untuk kadar air pada rimpang jahe kering, yakni maksimum $12 \%$. Merdhikawati (2006) mengemukakan bahwa kandungan air pada sampel jahe mempengaruhi pelarutan senyawa yang terekstrak. Semakin rendah kandungan air pada sampel, akan semakin maksimal proses ekstraksi. Ketaren (1985) mengungkapkan susut berat pengeringan jahe sekitar $70 \%$ dari berat segarnya. Jahe yang bermutu baik mempunyai kadar air tidak lebih dari $10 \%$, sedangkan jahe bermutu rendah berkadar air sekitar $25 \%$.

Oleoresin atau ekstrak jahe yang diperoleh berupa larutan kental berwarna kuning gelap sampai coklat gelap, dengan aroma khas rempah, hangat, berbau manis, serta rasa pedas dan hangat yang menggigit. Adapun dari 100g jahe kering, 
diperoleh kadar oleoresin dapat dilihat pada tabel 1.

Kadar oleoresin yang diperoleh dari ketiga sampel setelah dirata-ratakan adalah sebesar $8,72 \%$. Sedangkan dari hasil penelitian Merdhikawati (2006) dengan menggunakan metode yang sama (metode ekstraksi perkolasi suhu ruang dengan pelarut etanol), dari $\pm 50 \mathrm{~g}$ sample jahe merah menghasilkan kadar oleoresin sebesar 6,16\%. Dalam penelitian Sutarno et al. (1999) dalam Merdhikawati (2006), jahe yang diekstraksi dengan pelarut organik menghasilkan 3,5-10\% oleoresin, yang mengandung $15-30 \%$ komponen yang mudah menguap.

\section{Isolasi (Ekstrak Gingerol)}

Bobot hasil isolasi gingerol yang diperoleh dari perlakuan beberapa konsentrasi dapat dilihat pada tabel 2. Dari tabel 2 terlihat bahwa pada perlakuan dengan konsentrasi 1,0N didapatkan bobot hasil isolasi yang paling tinggi, yaitu $0,61 \mathrm{~g}$, kemudian diikuti pada konsentrasi $\mathrm{KOH} \quad 0.5 \mathrm{~N}$ sebesar $0,51 \mathrm{~g}$, dan yang terakhir pada konsentrasi $\mathrm{KOH} \quad 0,1 \mathrm{~N}$ sebesar $0,19 \mathrm{~g}$.

\section{Identifikasi}

Senyawa Gingerol diindentifikasi dengan menggunakan metode Kromatografi Lapis Tipis (KLT) dan Kromatografi Gas Spektroskopi Massa (GC-MS).

\section{Identifikasi gingerol dengan Kromatografi Lapis Tipis (KLT)}

Nilai waktu alir (RF) dari penelitian yang dilakukan dibandingkan dengan penelitian terdahulu tertera pada tabel 3 .

Hasil pemisahan pada konsentrasi KOH 0,5N dengan KLT ditampilkan dalam gambar 1. Nilai waktu alir (RF) merupakan perbandingan jarak yang ditempuh oleh senyawa terhadap jarak yang ditempuh pelarut. Nilai waktu alir (RF) senyawa yang diduga sebagai senyawa aktif gingerol adalah spot dengan nilai $R f$ antara 0,35-0,37 (Spot 2). Fakta ini didukung oleh pengujian standard 6Gingerol yang berasal dari Wako Pure Chemical Industries (Osaka Japan), spot terbentuk dengan nilai Rf $0,35-0,37$. Hal ini membuktikan bahwa senyawa gingerol teridentifikasi dalam hasil penelitian yang dilakukan.

Tabel 1. Perolehan Oleoresin pada Hasil Ekstraksi Sampel Jahe Merah

\begin{tabular}{llcc}
\hline Ke- & Bobot Sampel & Bobot Oleoresin & Kadar Oleoresin \\
\hline 1 & $100,0089 \mathrm{~g}$ & $8,85 \mathrm{~g}$ & $8,85 \%$ \\
2 & $100,0150 \mathrm{~g}$ & $8,55 \mathrm{~g}$ & $8,55 \%$ \\
3 & $100,0250 \mathrm{~g}$ & $8,80 \mathrm{~g}$ & $8,80 \%$ \\
\hline \multicolumn{3}{c}{ Rata-rata } \\
\hline
\end{tabular}

Tabel 2. Perolehan Bobot Hasil Isolasi Jahe Merah
Konsentrasi KOH
Bobot Hasil Isolasi

$\begin{array}{ll}0,1 \mathrm{~N} & 0,19 \mathrm{~g} \\ 0,5 \mathrm{~N} & 0,51 \mathrm{~g} \\ 1,0 \mathrm{~N} & 0,61 \mathrm{~g}\end{array}$


Tabel 3. Perbandingan Nilai RF Berdasarkan Pustaka dan Hasil Penelitian

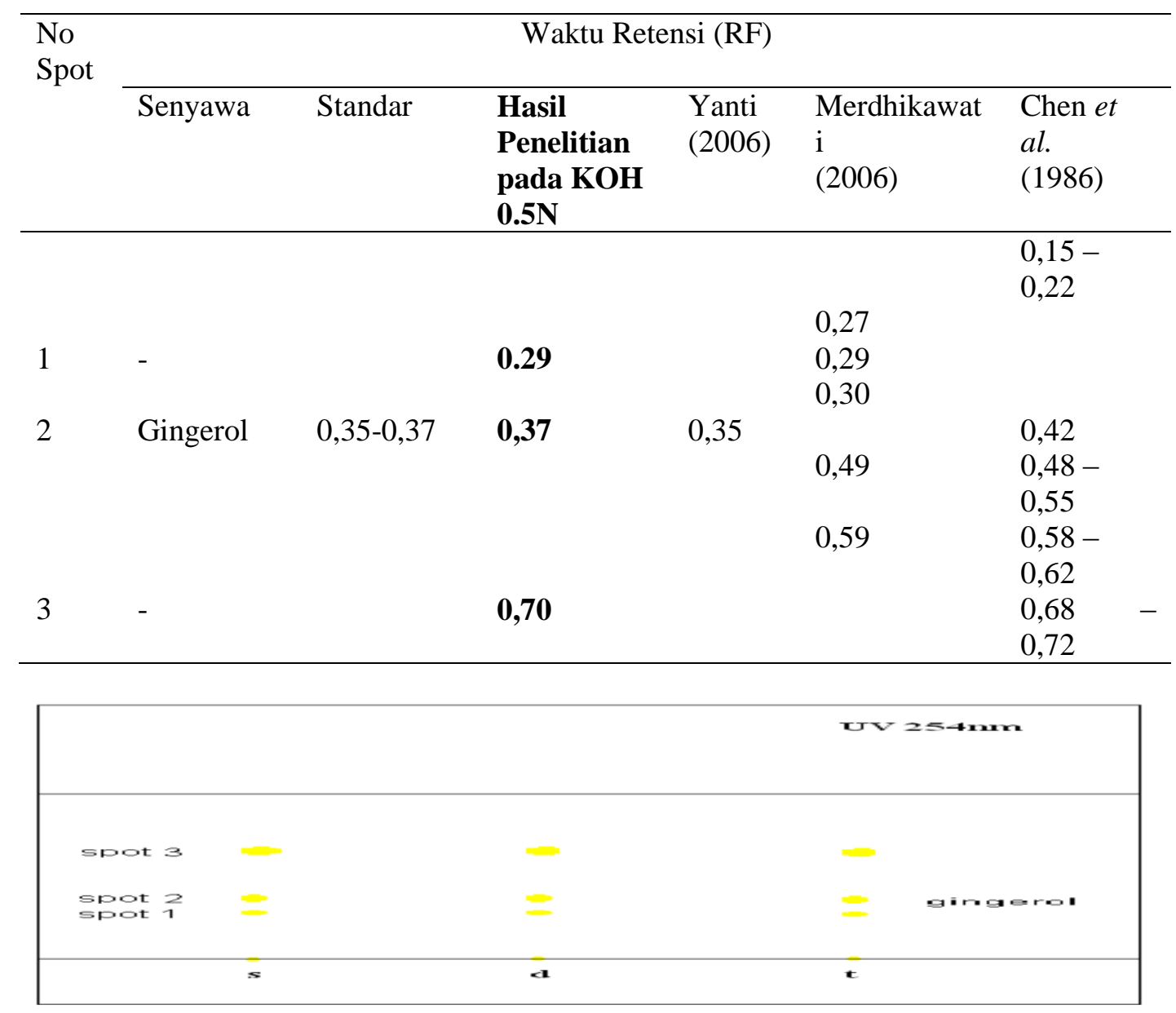

Gambar 1. Pola Pemisahan Sample dengan KLT

Dari hasil penelitian, terdapat 1 buah spot yang dapat dikatakan memiliki wilayah waktu alir (RF) yang sama dengan penelitian Merdhikawati, yaitu spot no. 1 $(0,29)$, lalu 1 buah spot memiliki wilayah Rf yang sama dengan penelitian Yanti (2006), yaitu spot no. $2(0,37)$, sedangkan spot no. 3 memiliki wilayah Rf yang sama dengan penelitian Chen et al. (1986) dalam Hayati (2005), yaitu spot no. $3(0,70)$.

\section{Identifikasi Gingerol dengan Kromatografi Gas - Spektroskopi Massa (GC-MS)}

Setelah dilakukan identifikasi senyawa gingerol dengan menggunakan
GC-MS, maka mendapatkan hasil stertera pada tabel 4.

Dari hasil penelitian ini terlihat bahwa pada konsentrasi $\mathrm{KOH} \quad 0,5 \mathrm{~N}$ didapatkan gingerol dengan \%kemelimpahan yang paling besar, yaitu $6,13 \%$. Bila konsentrasi $\mathrm{KOH}$ dinaikkan menjadi $1.0 \mathrm{~N}$, \%kemelimpahan menurun menjadi $0.49 \%$, sedangkan pada konsentrasi $\mathrm{KOH} 0.1 \mathrm{~N}$ tidak didapatkan senyawa gingerol sama sekali. Menurut Anonim, 1996., [6]-Gingerol (C17H26O4), (S)-5-hidroksi-1-(4-hidroksi-3-

metoksifenol)-3-dekanon, memiliki berat molekul $294.38 \mathrm{~g} / \mathrm{mol}$. Dari hasil identifikasi dengan menggunakan GC-MS pada sample, menunjukkan massa molekul yang dapat dikategorikan sebagai gingerol, yakni 294.2 m/e. Konsentrasi $\mathrm{KOH}$ yang 
paling optimum dapat mengisolasi gingerol adalah dengan konsentrasi $0,5 \mathrm{~N}$, hal ini dapat dilihat dari \%kemelimpahan pada tabel 5. Sedangkan $\mathrm{KOH}$ dengan konsentrasi $0,1 \mathrm{~N}$ sama sekali tidak dapat mengekstrak gingerol. Sedangkan jika dihitung secara kasar kadar (\% w/w) gingerol yang diperoleh dari $100 \mathrm{~g}$ sampel jahe merah pada konsentrasi $\mathrm{KOH} 0,5 \mathrm{~N}$ adalah sebesar $0.80 \%$. Diagram fragmentasi senyawa gingerol dapat dilihat pada gambar 2 .

Garis tegak lurus menunjukkan besarnya arus listrik yang diterima oleh alat pencatat arus yang berarti banyaknya ion datang ke detektor. Tiap garis menunjukkan fragmen atau pecahan berbeda yang dihasilkan ketika ion molekuler (dalam diagram ini pada $\mathrm{m} / \mathrm{e}=$ 294) pecah. Ion-ion molekuler yang tidak stabil akan terpecah menjadi bagian-bagian yang lebih kecil, yakni berupa radikal bebas. Garis paling tinggi pada diagram (dalam diagram ini pada $\mathrm{m} / \mathrm{e}=137$ ) disebut "puncak dasar". Puncak dasar adalah puncak yang paling tinggi karena menunjukkan ion fragmen yang paling banyak terbentuk, atau karena ia merupakan ion yang stabil (Anonim, 2008b). Mekanisme penguraian senyawa gingerol hingga diperoleh radikal bebas yang stabil yang disebut sebagai "puncak dasar" dapat dilihat gambar 3 .

Tabel 4. Identifikasi Senyawa Gingerol dengan Menggunakan GC-MS pada Sampel

\begin{tabular}{cccc}
\hline $\begin{array}{c}\text { Konsentrasi } \\
\text { KOH }\end{array}$ & $\begin{array}{c}\text { Waktu Retensi } \\
\text { (menit) }\end{array}$ & $\begin{array}{c}\text { Bobot Molekul } \\
\text { Gingerol (g/mol) }\end{array}$ & \% Kemelimpahan \\
\hline $0,1 \mathrm{~N}$ & - & - & - \\
$0,5 \mathrm{~N}$ & 16,172 & 294,2 & 6,13 \\
$1,0 \mathrm{~N}$ & 16,621 & 294,2 & 0,49 \\
\hline
\end{tabular}

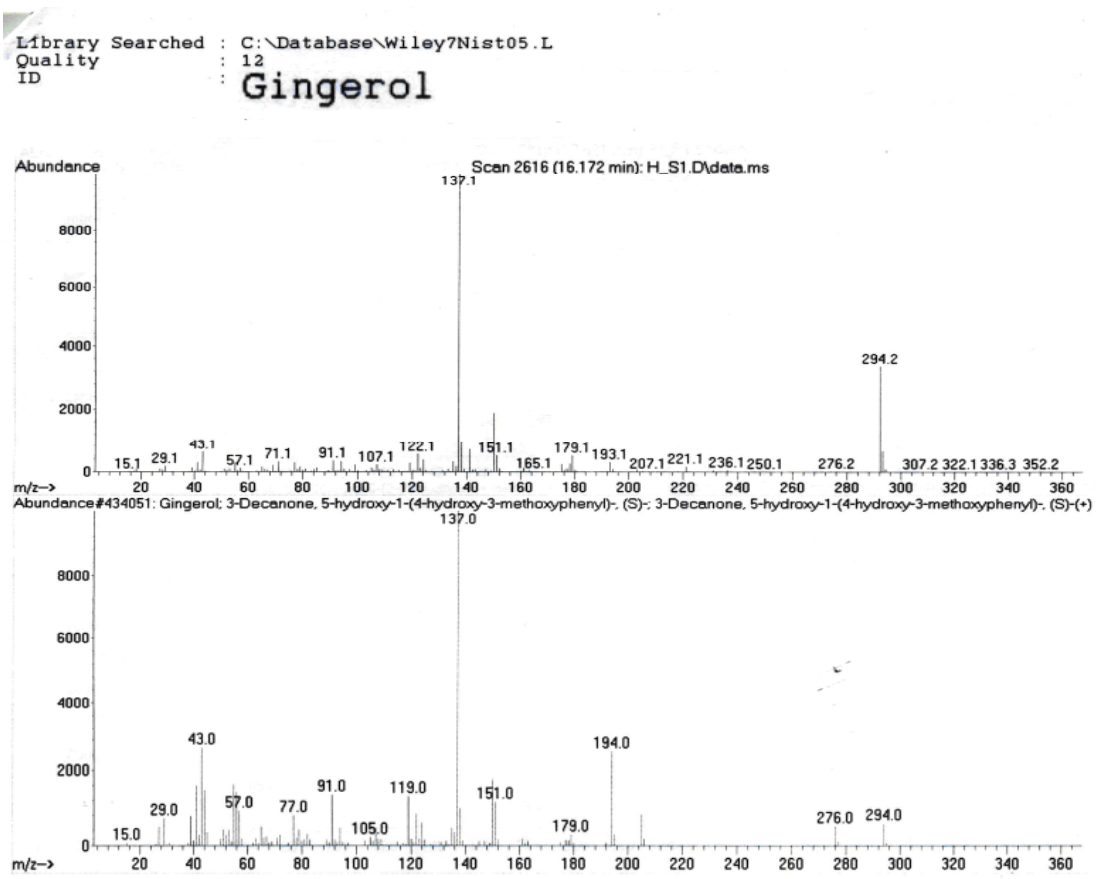

Gambar 2. Diagram Fragmentasi Senyawa Gingerol 


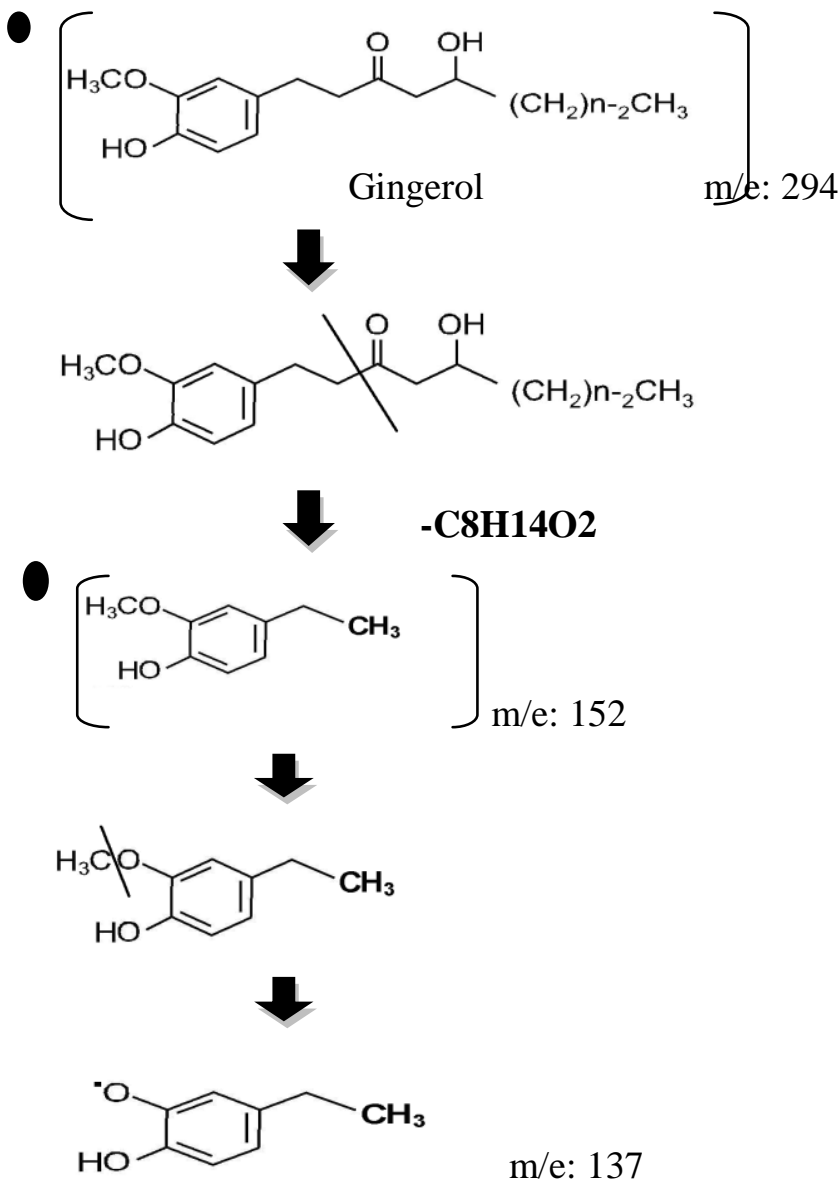

Gambar 3. Mekanisme Penguraian Senyawa Gingerol dari m/e : 294 menjadi m/e : 137

Radikal bebas adalah suatu atom atau gugus yang memiliki elektron yang tidak berpasangan. Radikal bebas yang terbentuk di ubah menjadi radikal bebas stabil dan tak reaktif. Hal ini dikarenakan radikal bebas yang dihasilkan, distabilkan oleh resonansi dengan cara disebar (delokalisasi) oleh cincin aromatik, yakni ikatan rangkap tersebut terus dipindahkan kepada ikatan disebelahnya.

\section{Teridentifikasinya beberapa senyawa lain}

Menurut Chen et al. (1986) dalam Hayati (2005) gingerol akan berubah menjadi senyawa turunan shogaol selama pengeringan rimpang jahe karena adanya dehidrasi senyawa gingerol. Reaksi gingerol menjadi shogaol akan terjadi sangat cepat dalam suasana basa dan dapat terjadi pada suhu kamar. Senyawa shogaol yang teridentifikasi dapat dilihat pada tabel 5 .

Senyawa shogaol lebih banyak didapatkan pada sample 3 (penambahan $\mathrm{KOH} 1 \mathrm{~N}$ ) dengan \%kemelimpahan sebesar 4.59\%, Bila konsentrasi $\mathrm{KOH}$ diturunkan menjadi $0,5 \mathrm{~N} \%$ kemelimpahan menurun menjadi 4,00\%, sedangkan pada $\mathrm{KOH}$ $0,1 \mathrm{~N}$ tidak ditemukan adanya shogaol. Reaksi pembentukan shogaol dapat dilihat pada gambar 4.

Reaksi gingerol menjadi shogaol akan terjadi sangat cepat dalam suasana basa dan dapat terjadi pada suhu kamar (Chen et al., 1986 dalam Hayati 2005). Dalam suasana asam reaksi berlangsung 
lambat tapi dengan suhu tinggi reaksi akan berlangsung cepat. Zingeron merupakan hasil degradasi gingerol akibat suhu tinggi dengan adanya alkali. Komponen ini terbentuk dengan adanya pemanasan pada suhu diatas $200^{\circ} \mathrm{C}$ dalam

suasana basa $5 \% \mathrm{NaOH}$. Tetapi pada hasil penelitian ini tidak ditemukan adanya senyawa zingeron, hal ini dimungkinkan senyawa gingerol belum berubah menjadi zingeron. Pada suasana basa $\mathrm{NaOH}$ pekat, akan terjadi reaksi kopling atau sering disebut reaksi penggandengan (kopling) oksidatif. Reaksi tersebut merupakan istilah dalam kimia organik yang mengacu pada sekelompok reaksi kimia organologam di mana dua radikal hidrokarbon digandengkan (kopling) dengan bantuan katalis yang mengandung logam. Reaksi penggandengan ini sebagian besar melibatkan senyawa turunan fenol. Sehingga jika reaksi terus berkelanjutan akan terbentuk senyawa polimer. Selain gingerol yang memiliki puncak dasar dengan $\mathrm{m} / \mathrm{e} 137$, ternyata shogaol pun memiliki nilai puncak dasar yang sama dengan gingerol, yakni pada m/e 137 . Senyawa lain yang selalu ditemukan dengan kondisi \% kemelimpahan terbesar pada setiap sampel adalah senyawa homovanilil alkohol dengan data pada tabel 6.

Tabel 5. Identifikasi Senyawa Shogaol dengan Menggunakan GC-MS pada Sampel

\begin{tabular}{cccc}
\hline $\begin{array}{c}\text { Konsentrasi } \\
\text { KOH }\end{array}$ & $\begin{array}{c}\text { Waktu Retensi } \\
\text { (menit) }\end{array}$ & $\begin{array}{c}\text { Bobot Molekul } \\
\text { Shogaol (g/mol) }\end{array}$ & \% Kemelimpahan \\
\hline $0,1 \mathrm{~N}$ & - & - & - \\
$0,5 \mathrm{~N}$ & 15,803 & 276,2 & 4,00 \\
$1,0 \mathrm{~N}$ & 15,773 & 276,2 & 4,59 \\
\hline
\end{tabular}<smiles>CCCCCCC(=O)CCc1ccc(O)c(OC)c1</smiles>

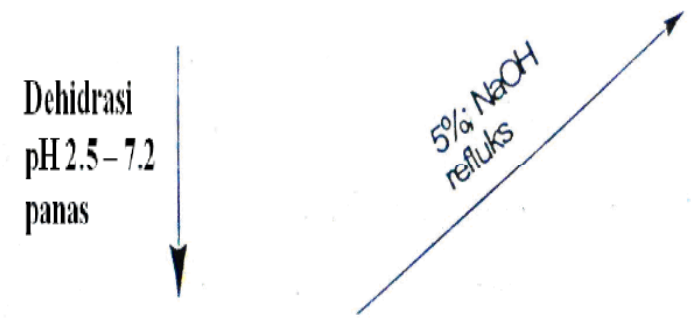<smiles>CCCCCCCCCC(=O)C=CCc1ccc(O)c(OC)c1</smiles>

Gambar 4. Struktur Gingerol, Shogaol, Zingeron, dan Bagan Pembentukan Komponen Turunan Gingerol (Chen et al.,1986 dalam Hayati, 2005) 
Tabel 6. Identifikasi Senyawa Homovanilil Alkohol dengan Menggunakan GC-MS pada Sampel

\begin{tabular}{cccc}
\hline $\begin{array}{c}\text { Konsentrasi } \\
\text { KOH }\end{array}$ & $\begin{array}{c}\text { Waktu Retensi } \\
\text { (menit) }\end{array}$ & $\begin{array}{c}\text { Bobot Molekul } \\
\text { Homovanilil alkohol } \\
\text { (g/mol) }\end{array}$ & \% Kemelimpahan \\
\hline $0,1 \mathrm{~N}$ & 8.345 & 168.1 & 19.55 \\
$0,5 \mathrm{~N}$ & 8.511 & 168.1 & 23.22 \\
$1,0 \mathrm{~N}$ & 8.308 & 168.1 & 23.22 \\
\hline
\end{tabular}

Senyawa homovanilil alkohol ini memiliki nama lain 4-hidroksi-3metoksifenol, dengan rumus molekul $\mathrm{HOC} 6 \mathrm{H} 3(\mathrm{OCH} 3) \mathrm{CH} 2 \mathrm{CH} 2 \mathrm{OH}$ dan bobot molekul 168,19 dengan titik leleh $113{ }^{\circ} \mathrm{C}$. Senyawa ini tidak ditemukan pada oleoresin (ekstrak jahe), tetapi senyawa ini didapatkan dari proses isolasi yang telah dilakukan (Anonim, 2008a).

Selain pada gingerol dan shogaol, puncak dasar dengan m/e 137 ditemukan pula pada fragmen homovanilil alkohol. Berdasarkan hasil penelitian, puncak dasar dengan m/e 137 tidak hanya ditemukan pada fragmen gingerol, tetapi juga didapatkan pada fragmen shogaol dan homovanilil alkohol. Hal ini semakin menguatkan bahwa m/e : 137 adalah ion yang paling banyak terbentuk dan merupakan ion yang stabil. Lalu sesuai dengan hipotesis awal bahwa senyawa fenol yang bersifat asam dapat direaksikan dengan basa membentuk garam yang larut dalam air. Dan hal ini terbukti dari hasil identifikasi dengan menggunakan GC-MS, bahwa sebagian besar senyawa yang terisolasi oleh $\mathrm{KOH}$ adalah senyawa golongan fenol, yakni gingerol, shogaol dan homovanilil alkohol.

\section{KESIMPULAN DAN SARAN}

\section{KESIMPULAN}

Berdasarkan hasil penelitian dan identifikasi yang telah dilakukan pada sample jahe merah, dapat disimpulkan bahwa semakin tinggi konsentrasi $\mathrm{KOH}$ semakin besar bobot gingerol yang diperoleh, bobot tertinggi diperoleh pada perlakuan basa $\mathrm{KOH} 1 \mathrm{~N}$, sedangkan \% kemelimpahan gingerol terbesar pada $\mathrm{KOH} 0.5 \mathrm{~N}$. Hasil isolasi gingerol masih belum murni. Senyawa homovanillil selalu didapatkan dengan $\%$ kemelimpahan cukup besar pada setiap sampel. Ion dengan nilai $\mathrm{m} / \mathrm{z}$ : 137 adalah ion yang paling banyak terbentuk dan merupakan ion yang stabil. Sebagian besar senyawa yang terekstraksi oleh $\mathrm{KOH}$ adalah senyawa golongan fenol, seperti gingerol, shogaol dan homovanilil alkohol.

\section{SARAN}

Perlu penelitian pengembangan mengenai metode ekstraksi gingerol yang lebih baik antara lain dengan cara penambahan larutan $\mathrm{KOH}$ dengan rentang konsentrasi antara $0,5-1,0 \mathrm{~N}$ dan oleoresin (ekstrak jahe) ditambahkan larutan $\mathrm{HCl}$ terlebih dahulu sebelum penambahan kloroform yang pertama.

\section{DAFTAR PUSTAKA}

Hayati, E.K. 2005. Pemilihan Metode Pemisahan untuk Penentuan Konsentrasi Gingerol dan Pola Respon Fourier Transform Infrared pada Rimpang Jahe Emprit (Zingiber officinale, Roscoe). [Tesis]. Institut Pertanian Bogor.

Ketaren, S. 1985. Pengantar Teknologi Minyak Atsiri. UI Press, Jakarta

Merdhikawati, D. 2006. Perbandingan Teknik Ekstraksi dalam Analisis 
Gingerol pada Jahe Merah (Zingiber officinale, Roscoe). [Skripsi]. Universitas Nusa Bangsa, Bogor.

Rostiana, O., B. Nurliani, R. Mono. 2005. Budidaya Tanaman Jahe. BPPP. Balai Penelitian Tanaman Obat dan Aromatika.

Winarti C., N. Nurdjanah. 2005. Peluang Tanaman Rempah dan Obat sebagai Sumber Pangan Fungsional. Jurnal Litbang Pertanian, 24(2). Balai Penelitian dan Pengembangan Pascapanen Pertanian.

Anonim. 2008b. http://www.chem-istry.org/ [09 Januari 2009]
Yanti N. 2006. Antioksidan Ekstrak Jahe Merah ((Zingiber officinale, Roscoe) dengan Metode Diena Terkonjugasi pada Minyak Kedelai. [Skripsi]. Universitas Nusa Bangsa. Bogor.

Sumber Internet :

Anonim. 2008a.

http://www.chemexper.com/search/cas/238 0781.html. [ 03 Desember 2008] 